\title{
Modeling economic vulnerability: As applied to microbiological contamination on the Thau Lagoon shellfish farming industry
}

\author{
José A. Pérez Agúndez ${ }^{a}{ }^{*}$, Eden Yimam ${ }^{c}$, Pascal Raux ${ }^{c}$, Hélène Rey-Valette ${ }^{b}$, Sophie Girard ${ }^{a}$
}

\author{
a Ifremer, UMR-M101 AMURE, France \\ b LAMETA, University of Montpellier 1, France \\ ${ }^{\mathrm{c}}$ Université de Brest, UMR M101 AMURE, OSU-IUEM, France \\ *: Corresponding author : José A. Pérez Agúndez, tel.: +33298224360 ; fax: +33298224776 ; \\ email address : jose.perez@ifremer.fr
}

\begin{abstract}
:
The economic impacts induced by the harmful effects of pollution or negative natural events are heterogeneous and depend on the event type and intensity, as well as the characteristic make-up of agents affected. This vulnerability analysis evaluates how each agent (or group of agents) is potentially affected by an external stress or event with respect to risk of exposure, sensitivity or intensity of subjection, and coping capacity of these agents in order to avoid or reduce its effects. Using a comparative formulation model, the aim of this paper is to quantifiably assess the vulnerability of shellfish farming linked to bacteriologic pollution. An analysis of the vulnerability concept and the construction of pertinent indicators are presented. The analysis is then applied to the Thau Lagoon, a shellfish farming production area of the French Mediterranean; this industry is threatened by different ecosystem disturbances including the increase of microbiologic contaminations of the lagoon's catchment which often results in commercial bans. The commercial bans associated to microbacteriologic pollution have a varied effect on shellfish farming companies. A field survey was used to gather information about the sector and the companies themselves. This paper shows that the strongest companies (minimally affected by commercial bans compared to other companies in the sample) invest in storage technology and product diversification, which mitigates negative impacts from commercial bans. Companies that have large capital are no less impacted than those without much capital. Potential policy and community structured assistance can support the shellfish industry using this type of quantitative vulnerability formulation.
\end{abstract}

\section{Highlights}

Shellfish farming is submitted to many environmental risks including bacteriological pollution. The economic impacts related to commercial bans are heterogeneous depending on commercial and production strategies of companies. The paper builds vulnerability indicators for companies related to the contamination risk of bacterial contamination observed. Investments in storing capacity represent a current resilience vector to cope commercial bans. 


\section{Introduction}

Coastal zones are increasingly subjected to anthropogenic pressures such as pollution and destruction of natural habitats which generally result in sustainability failures. These issues are treated as externalities since polluters do not integrate the economic effects that their production or consumption functions induce. In order to implement management processes targeting the reduction of social costs, the monetary evaluation of environmental impacts needs to be considered as a key element in coastal zone economic assessments.

However, monetary evaluation used for Environmental Impact Assessments (EIA) is not often comprised of the main drivers for sound environmental policy making, but only a short run process of compensation, remediation or project analysis based on Cost Benefit Analysis (CBA). Costs based on monetary evaluation as the sole indicator used in conventional CBA is unable to describe reciprocal influences between social, economic and environmental components of anthropo-ecosystems. All the complexities of the ecosystems, their dynamics, and the broad concept of sustainability are impossible to encapsulate in one single indicator (Simon and Proops, 2000). Moreover, monetary evaluation of impacts does not offer a detailed view of how agents are affected by external stresses but only how much they have been affected at a moment due to a particular event. These effects should include qualitative information such as non market values, natural environment, social and individual behaviour, risk perception, and governmental controls and influence.

Ideally rent dynamics would be used as absolute vulnerability determinants and provide a global objective vulnerability index. A cost analysis on shellfish producers would have also provided an interesting outlook on company behavior facing stress. However, there is no available economic information for numerous primary sectors such as shellfish farming. Moreover, this sector is structured by small family-owned companies with no accounting. This makes it too complex or no accurately feasible to accurately assess economic impacts of any ecological event.

Given the lack of information, the proposed vulnerability framework analysis constitutes an alternative method for assessing the heterogeneous impacts of external stresses. It enables providing qualitative information for decision making processes related to short and long run consequences of pollution events. This framework integrates, using comparative analysis, the degree in which: (1) individuals or groups of agents are exposed to the stresses analysed, (2) the extent to which they are sensitive to its effects and (3) which implementable mechanisms are available in order to mitigate or avoid these stresses.

The ideas and concepts concerning vulnerability have been explored extensively by the scientific community. Perceptions, definitions and explanations regarding vulnerability are diverse according to its application and adaption to scientific fields and frameworks (Pelling, 2003; Turner et al., 2003; White et al., 2005; Taubenböck et al., 2007). De Sherbinin et al. (2007) describe vulnerability as a state of a system or one of their elements which are likely to experience harmful exposure to hazard, perturbations, or stresses". Human and nonhuman factors or processes dictate the level of impact and intensity a community or population experiences facing external stresses and pressures (Taubenböck et al., 2007). These factors can be external, (some of them out of the individual's control), and/ or internal, including structural and temporary states determining their resilience capacity towards implementing adaptive responses after a shock, a crises or a stress. The concept of vulnerability has been formalized by White et al., (2005) using the following equation:

Vulnerability $=($ Exposure $\times$ Sensitivity/ Coping capacity $)$ 
The degree of vulnerability is directly proportional to the intensity of exposure and sensitivity and inversely proportional to coping capacity. Exposure is the living relation of a community or population in respect to a hazard, which is identified by physical location and society (Taubenböck et al., 2007; White et al., 2005). A wide range of external factors from climate change to environmental events plays a significant role in developing the exposure concept (Mohan, 2010). Sensitivity indicates resistance capacity, but does not address the ability to respond (Ippolito, 2010); similar to a person with an allergy, sensitivity is innate resistance and not by response (which would include medication and treatment). This involves a concept that takes into account those human and non-human variables that create a discrepancy in impact levels despite similar exposure (White et al., 2005). From an economic perspective, sensitivity can be understood as the marginal change of utility or profit (Hambry, 2002). This means that sensitivity can be organized and evaluated by a single measurement index (Stelzenmüller, 2009). Finally, coping capacity as a vulnerability component is the rational ability to adjust in the face of change and focuses on resource management and efficiency during periods of crises or stress. Strategies employed to manage stress are shortterm in nature and are designed to reduce the impacts from exposure and sensitivity (White et al., 2005). Since vulnerability is not static, it adjusts accordingly to the variables associated with the exposure, sensitivity and coping capacity components.

A proper vulnerability assessment must discover who is vulnerable, and then determine where and why; responses to these questions can then facilitate decision-making (Taubenböck et al., 2007). Measurement of vulnerability to a stress or hazard takes into account $(i)$ the relationship between human and environmental systems; (ii) consequential stresses that are produced (iii) and adaptive response(s) of the systems involved (Turner et al., 2003). It is important that a quantitative evaluation of vulnerability concentrates on specific stresses and populations because of the vast amount of possible indicators involved (Luers et al., 2003). The indicator pool must be properly managed; if it is too small, the assessment will have gaps of information, if it is too large, indicators will be under-valued (Munier, 2011).

This paper applies the vulnerability framework to the shellfish farming sector of the Thau Lagoon, which is the highest production area on the French Mediterranean coast (Girard et al., 2005). At the local scale, this sector is an important supplier of employment and revenues for the population. Its physical location is in a semi-enclosed lagoon situated at the base of a downstream area of several catchments; this implies that the breeding areas are threatened by the urban effluents charged in pollutants, particularly enteric bacteria (Fiandrino et al., 2003). The microbiologic contamination of the Thau Lagoon is the result of urban, industrial, agricultural or other anthropogenic activities discharging effluents to the upstream part of the catchments. Other animal effluents (dogs, birds, etc.) can contribute as well to the microbiological charge. Contamination of the Lagoon has been a recurrent issue since the birth of the local shellfish farming industry (Calvet, 1910). The extent of urbanization in littoral areas, which have increased by more than $40 \%$ since 1980, and the global development of anthropogenic activities, have consequently lead to an increase in environmental pressures and a decline in water quality (Mongruel et al 2013). The responses that companies can implement in case of pollution events are heterogeneous depending on their own capacities. These reactions raise the question of how much the companies of the sector are exposed to these events, and how they cope with them.

Vulnerability should be properly analyzed as a multi-factorial combination of effects (event independent) which potentially can affect individual firms. The environmental threats the shellfish farming companies must face concern (i) anoxic crises locally named malaïgue" (Harzallah and Chapelle, 2002; Chapelle et al., 2001), (ii) harmful algal blooms (HAB), (iii) summer mortalities of oysters affecting juveniles in spring and adults in summer (Fleury et al., 2001), and (iv) episodes of excessive enteric bacteria found in water supply . A more global analysis would require a larger framework, and the modelling multi-objective issues 
which will be developed in future research. The aim of this paper only focuses on microbiologic pollution events and builds a relevant framework of associated indicators.

\section{Material and Data Collection}

To achieve the vulnerability analysis of the shellfish farming sector, information about local companies was collected by a field survey in 2010 prepared in collaboration with local stakeholders. The survey was conducted from May to end of June 2010 and produced a final sample of 99 companies, which represents $19 \%$ of the total population (Gervasoni et al, 2011). The companies surveyed are located in all five of the Thau Lagoon municipalities (Mèze, Bouzigues, Loupian, Sète, and Marseillan). A representative sample was structured by stratifying the shellfish farming population in 4 classes; company size was considered the main criterion. The total volume of water masses available for breeding processes was considered to be a better proxy of company size the surface ares of production rights. This choice is determined by the specificities of the local production structures. The size of all production rights in this area is similar and measure 25 ares. Moreover, the ecological productivity of this area is the same independently of the spatial location of the concessions, only their bathymetries can be different. Consequently, the potential production of each production right can be approached by its volume of water column because it enables a higher load of animals. Four segments of size have been developed by available water volume; (1) less than $6000 \mathrm{m3}$, (2) 6001 to $10000 \mathrm{m3}$, (3) 10001 to $20000 \mathrm{~m} 3$, and (4) more than $20000 \mathrm{~m} 3$.

Table 1: $\quad$ Main statistics of the survey

\begin{tabular}{|c|c|c|c|}
\hline $\begin{array}{c}\text { Total } \\
\text { Population }\end{array}$ & $\begin{array}{c}\text { Companies } \\
\text { surveyed }\end{array}$ & $\begin{array}{c}\text { Rate of companies } \\
\text { surveyed }\end{array}$ & $\begin{array}{c}\text { Error rate of the } \\
\text { survey }\end{array}$ \\
\hline 550 & 100 & $19 \%$ & $6.9 \%$ \\
\hline
\end{tabular}

A second discretization criterion is the production and commercial specialisation of companies. The survey confirmed the functional make-up of the sector and its segmentation by company activity, in accordance with the studies of Gangnery et al. (2003) and Mathe et al. (2006). There are four types of companies identified: (1) -simple producers" who are defined by companies that sell their proper production ${ }^{1}$ to other intermediaries or producers, (2) tocal market producers" that focus on producing and selling their own proper production. Their revenues from dispatching ${ }^{2}$ activities (excludes the commercialization of proper production) correspond to less than $20 \%$ of their total revenues, (3) Producers/ Dispatchers" which concentrate on selling their proper production, but also sell the production of other companies; their revenues from dispatching activities reach between 20 $\%$ and $60 \%$ of their total revenues and (4) Đispatchers" focused primarily on the selling of shellfish from other sources of production. Their revenues from dispatching activities are higher than $60 \%$ of their total revenues. This categorization provides a functional perspective to vulnerability and sheds light on the different activities performed within the sector. It also should be noted that the most revenue is generated from the commercialization of oysters and mussels; other shellfish are sold on a minor scale (Gangnery et al., 2003).

\footnotetext{
${ }^{1}$ Proper production is referenced throughout this paper. This involves the commercialization of products grown by the company on their proper shellfish farms. All other products are excluded.

${ }^{2}$ Dispatching refers to the commercialization of shellfish which have not be internally growth by companies but bought from other producers. For example, when a company $X$ sells a product grown by company $Y$, this is considered "dispatching." The company is also considered a "dispatcher."
} 
The questionnaire consisted of over 350 questions and 26 sections concerning the practices, financials and social aspects of the shellfish farming industry surrounding the Thau Lagoon. It has been devised in homogeneous sections aiming to describe (i) the general characteristics of each company (and their entrepreneur) as well as their global perception of the structure and the dynamics of the sector, and (ii) their economic strategies in terms of production, dispatching and cultural practices. There were some specific sections related to the impacts of environmental events and the responses implemented by companies to reduce their negative effects.

The management of pollution events is conducted at the production area scale, which means that if a high bacterial concentration is detected from a local control point, a commercial ban is declared for all companies for a variable period of time; depending on the severity of contamination, mussels, oysters and or clams can be banned. During the duration of these bans, companies are restricted from selling product not yet removed from the Thau Lagoon. Consequently, the risk of being impacted by a ban is equal for all companies. However, in spite of this equal risk, the effects of commercial bans are heterogeneous and depend on the characteristics of the companies. Several questions have been included in the survey for capturing these effects as well as the behavior of entrepreneurs when facing commercial bans.

As part of the survey, the companies were asked to recall any impacts caused by commercial bans within the past 5 years (from the date of the survey, 2010); 43\% stated that they do not remember any particular impact ${ }^{3}$. Of the companies that did admit to being impacted by commercial bans (30\%), the principal adaptive strategy employed was the implementation of storage mechanisms for safeguarding products. The storage process involves placing shellfish products in external tanks in case of contamination alarm, mainly due to heavy rains, before they are exposed to contamination. The shellfish safeguarded can be sold during commercial bans and thus minimizes the potential impacts to the company.

The registration and monitoring of microbiologic pollution events affecting shellfish farming is registered under the national network of the French Research Institute for Exploitation of the Sea (Ifremer). Data provided by this network was used to comprehend the occurrences of commercial bans. At the whole, seven commercial bans due to microbiologic pollution have been observed; they have occurred most frequently in autumn. This is consistent since the annual pluviometry is higher in this season. The temporal structure of the bans is extremely important since the commercial activity pattern is seasonal and concentrated during specific periods of the year. The Christmas season accounts for almost half the annual revenue of shellfish farming companies and consequently, a pollution event during this period can have significant economic consequences for local companies.

\section{The Vulnerability Framework}

\subsection{Building vulnerability indicators}

The vulnerability assessment is based on multi-criteria indicators which are built under an 8 step method divided into 3 processes (Turner et al., 2003, Schröder et al., 2005). The first process, pre-modeling", concerns the (1) identification of the study area, (2) the collection of information and (3) the hypothesis construction with regards to who is vulnerable to what" (Taubenböck et al., 2007). The second process, modeling", encompasses (4) the development of a causal model of vulnerability, (5) the identification and association of indicators to vulnerability components, (6) the execution of the models and (7) the

\footnotetext{
${ }^{3}$ This does not mean no impact was felt. Companies have poor record keeping practices and often do not properly assess past events.
} 
implementations of future projections based on results from data available. The last process, post-modeling", is (8) the diffusion of information to stakeholders.

Indicators are derived from the survey conducted, but it is not the only source of information. Building on the framework that has been presented by Mohan et al. (2010) a catered step by step indicator construction process was developed. When the information gathered from the survey is divided into internal and external factors (Villagran de Leon, 2006), a filtering process is needed to select the pertinent indicators; this is done by establishing a profile structure. This study has produced five profiles that capture the linkage between the shellfish farming sector and commercial bans due to microbiological contamination in the Thau Lagoon. The sole environmental profile is stress due to contamination. The other four profiles focus on company behavior and constitution. The definition of each profile is explained below:

$\checkmark$ Stress: probability of a commercial ban based on location and products affected.

$\checkmark$ Production: company shellfish farming production based on annualized data.

$\checkmark$ Sales strategy: reflects the diversity of commercial strategies of companies.

$\checkmark$ Structure: for the purpose of this paper, structure is defined as the make-up of the company which includes labor, technology resources and size.

$\checkmark$ Performance: this takes into account financial strategy and revenue.

The completion of the indicator profiling phase allows for a concise view of indicators and their linkage to the vulnerability components. The indicator profile framework diagram (Figure 1) shows how the indicators pass through each phase. The fourth column, formulation, helps convey the indicator relationship within the component.

Figure 1: $\quad$ Indicator Profile Framework

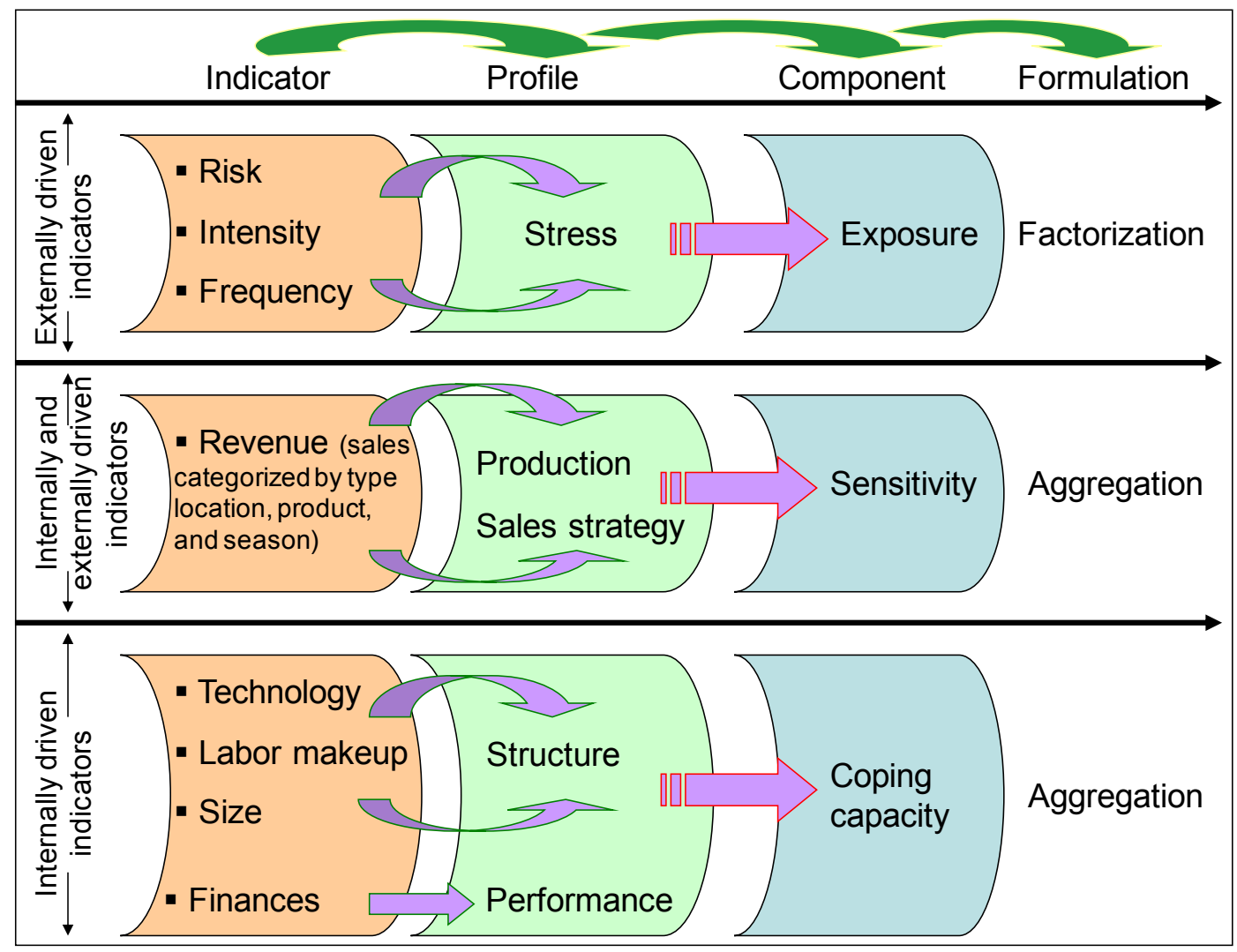


When indicators are placed in their proper profile group, redundancies are found and excess indicators can be filtered out. In following the advice of Munier (2011), the indicator set was determined holistically in order to manage repetition and component placement. For example, revenue categorization is a key part of the sensitivity component (noted in diagram of Figure 1), but is also a measure of size in the coping capacity component.

All indicators built are discretized by scoring processes. The scores are set by comparing each individual with the entire sample. This is a way of normalizing the information gathered from varied indicators and components. The global vulnerability assessment is made by the sum of scores assessed by indicator which is divided by the maximum score feasible. The vulnerability score discovered is comparative and applicable only to the context of the Thau Lagoon and the study's sample.

\subsection{Vulnerability Assessment for shellfish farming}

This paper is based on the construction of indicators that characterizes and segments the Thau Lagoon's shellfish farming population with respect to microbiologic contamination vulnerability. A scoring system is developed for each of the three components (exposure, sensitivity and coping capacity), which in turn is used to get a vulnerability score.

The indicators of the exposure component express the risk, intensity and frequency of commercial bans for each of the four seasons of the year; this probability assessment is based on historical occurrences available from 2004 to 2009. Relative to the commercial bans within the season, (1) risk signifies the probability that a product (type of shellfish) will be concerned, (2) intensity is the number of days incurred and (3) frequency is the number of occurrences by year.

$$
E_{s}=R_{s} \times Z_{s} \times U_{s}
$$

The exposure indicator is assessed by a simple factorization of these three driving indicators for each season of the year: R" is the risk of commercial ban for species $-s$," , $Z$ " is the intensity or length of the commercial bans in average number of days under commercial bans per season, and $\uplus$ " is frequency of bans in terms of total number of bans per season. This is structured on a seasonal basis because occurrence of commercial bans can be prevalent during a particular period and revenues follow seasonal patterns.

An administrative commercial ban implicates that all companies operating on or around the Thau Lagoon because there is no spatial sanitary management. If one control point signals a microbiological contamination, the entire area will be affected by the commercial ban. Thus, the exposure rate will be the same for all companies. It must be noted that this calculation corresponds with the sensitivity indicator structure. This is done to assure that all aspects of sensitivity are included in quantifying vulnerability. By doing this, the exposure component is efficiently associated with sensitivity; adhering to the concept that the two are perpetually related (Ippolito, 2010; Mohan et al, 2010; White, 2005; Hambry, 2002). The indicators of exposure assessed for the selfish farming sector are detailed in the table 2.

Table 2: $\quad$ Indicators of Exposure Component: Risk, Frequency and Intensity (data displayed is based on the 5 year period from $2004-2009$

\begin{tabular}{lcccc}
\hline & Winter & Spring & Summer & Autumn \\
\hline Risk (\# of bans on oysters or mussels) & 0 & 1 & 1 & 3 \\
Frequency (total \# of bans) & 0 & 1 & 2 & 4 \\
Intensity (average no. of days banned) & 0 & 22 & 9 & 12.25 \\
\hline \multicolumn{2}{c}{ (Source: data collected from the microbiologic observatory network of lfremer) }
\end{tabular}


Sensitivity is measured by the total revenue that can be potentially affected by commercial bans. The identification of revenues issued exclusively from internal shellfish growth into the Thau lagon is necessary. The company revenue is analytically decomposed by the different criteria related to type of activity, product affected, site of production, product source, and seasonality (cf. table 3)

Table 3: $\quad$ Factors of Revenue Decomposition for Sensitivity Component

\begin{tabular}{llllll}
\hline & Activity & \multicolumn{1}{c}{ Product } & Production & Dispatching & Season \\
\hline Description & $\begin{array}{l}\text { How products } \\
\text { are sold? }\end{array}$ & $\begin{array}{l}\text { What products } \\
\text { are sold? }\end{array}$ & $\begin{array}{l}\text { Where is the } \\
\text { production } \\
\text { source? }\end{array}$ & $\begin{array}{l}\text { Where is the } \\
\text { production } \\
\text { source? }\end{array}$ & $\begin{array}{l}\text { When are } \\
\text { products } \\
\text { sold? }\end{array}$ \\
\hline $\begin{array}{llllll}\text { Revenue } \\
\text { components }\end{array}$ & $\begin{array}{l}\text { - Shellfish } \\
\text { production }\end{array}$ & $\begin{array}{l}\text { - Oysters } \\
\text { - Mussels } \\
\text { - Dispatching }\end{array}$ & $\begin{array}{l}\text { - Other shellfish } \\
\text { - Outside the } \\
\text { Lagoon }\end{array}$ & $\begin{array}{l}\text { - Ohau Lagoon } \\
\text { - Outside of } \\
\text { the Lagoon }\end{array}$ & $\begin{array}{l}\text { - Spring } \\
\text { - Summer } \\
\text { - Fall }\end{array}$ \\
\hline
\end{tabular}

The combination of these factors constitutes 36 streams of revenue. To calculate sensitivity, the revenue potentially impacted by bans has been isolated by creating a dummy sensitivity coefficient. At this point, the binary composite coefficient $\triangle$ " (with values 0 or 1 ) is found by multiplying these three factors for each sensitivity indicator:

$D_{\text {mpgts }}=V \times L \times N$

$\forall$," $\leftarrow "$ and $\mathrm{A}$ " are dummy sensitivity variables. More precisely, $\forall$ " represents how company products are sold (from a company's proper production or from dispatching). Proper production is potentially affected by commercial bans but not necessarily products bought from other production areas. $L "$ is the production source; only proper production in the Thau lagoon is affected by contamination. $\mathrm{N}$ " is production sources of dispatched products. The indice -mpgts" represents revenues associated by different categories: -m" distinguishes revenue from only shellfish production and dispatching, p" distinguishes revenue by the type of shellfish species, - $g$ " distinguishes revenue sources of shellfish farming activities (Thau Lagoon or exterior), $t^{\prime \prime}$ indicates dispatching revenue sources (Thau Lagoon or exterior), and - $s$ " indicates the season.

The calculated $\rightarrow$ " coefficient is then applied to the revenue $¥$," which is associated with the sensitivity indicator and represents the Revenue which can be Potentially Impacted (RPI) by a commercial ban. The RPI is then divided by total revenue $\Psi_{t^{\prime \prime}}$ in order to normalize sensitivity data, $\mathbf{S}$ ":

$$
\begin{aligned}
& R P I_{\text {mpgts }}=D_{\text {mpgts }} \times Y_{m p g t s} \\
& S_{\text {mpgts }}=R P I_{\text {mpgts }} / Y_{t}
\end{aligned}
$$

The total sensitivity is the sum of revenue that can be potentially lost by a company due to commercial bans. The product of sensitivity and exposure can be considered as a proxy of the estimated total potential impact on revenue associated to commercial bans. The terms estimated" and potential" are important to mention because there is no certitude of the precise real impact due to a ban. Since exposure is based on probability and accurate financial data is not guaranteed for sensitivity, only a general estimation of potential impact can be achieved.

$$
I_{\text {mpgts }}=E_{m p g t s} S_{\text {mpgts }}
$$


+" is the potential impact in terms of percentage of revenue potentially affected by commercial bans, while $E^{\prime \prime}$ is the exposure and $S$ " is the sensibility.

Coping capacity indicators are developed using the structure and performance profiles (cf. table 4). The profile -structure" has three subcategories: technology, labor, and size characterized by indicators which have been preselected first and evaluated later based on producer responses to survey questions. A normalised scoring methodology has been applied for each indicator with a numeric value ranging from 1 to 4 ; a high score signifies a good coping capacity and versa low score signifies poor coping capacity. The indicator framework diagram (cf. figure 1) suggests that the relationship between indicators is aggregate; therefore the following formula is presented:

$\mathrm{C}_{\mathrm{t}}=\left(\sum_{\mathrm{i}=1}^{\mathrm{I}}\left(\mathrm{C}_{\mathrm{i}}\right) / \mathrm{C}_{\max }\right)$

We note that $-6 \mathrm{t}$ " is the total coping capacity and i" replaces -mpgts" detailed before. The global coping capacity by company is calculated as the sum of partial scores divided by the maximum possible score. The score grading is qualitative and comparative between companies. Scores values are then secondary and only used for comparing indicators between companies. The final result is a percentage, which corresponds with the normalization method used for the other components.

Table 4: $\quad$ Organization of Coping Capacity Indicators

\begin{tabular}{|c|c|c|c|}
\hline Profile & Subcategory & Indicator & Description \\
\hline \multirow{5}{*}{ Structure } & Technology & $\begin{array}{l}\text { Storage Capacity by } \\
\text { season }\end{array}$ & $\begin{array}{l}\text { Company in-house storage and } \\
\text { purification capacity to tonnage of } \\
\text { products sold ratio during each season. }\end{array}$ \\
\hline & \multirow{2}{*}{ Labor } & Full time employees & $\begin{array}{l}\text { Amount of full-time employees employed } \\
\text { by the company. }\end{array}$ \\
\hline & & Spouse Status & $\begin{array}{l}\text { Employment status of the spouse } \\
\text { company president/ owner }\end{array}$ \\
\hline & \multirow[b]{2}{*}{ Size } & Total Revenue & $\begin{array}{l}\text { Annual total revenue of the company from } \\
\text { shellfish activity }\end{array}$ \\
\hline & & Water volume & $\begin{array}{l}\text { Amount of water volume of the total } \\
\text { shellfish farming rights owned by the } \\
\text { company }\end{array}$ \\
\hline \multirow{3}{*}{ Performance } & \multirow{3}{*}{ Finances } & Credit Accessibility & Company access to credit/ loans \\
\hline & & $\begin{array}{l}\text { Cash Flow } \\
\text { Perception }\end{array}$ & Perception of company cash flow \\
\hline & & $\begin{array}{l}\text { Complimentary } \\
\text { Revenue }\end{array}$ & $\begin{array}{l}\text { Revenue that is not earned through } \\
\text { shellfish activities (fishing, etc.) }\end{array}$ \\
\hline
\end{tabular}

The technology subcategory refers to storage tanks used for safeguarding products during the commercial ban periods. From the survey conducted, it was observed that over $50 \%$ of shellfish farmers store their products in purification tanks during a commercial ban; thus giving the technology subcategory an important value. The seasonal storage capacity is taken into account because the volume of storage is constant but production and dispatching activity are seasonal. For example, an individual storage capacity can be sufficient in low activity seasons but insufficient in busy periods. 
The size subcategory is of considerable significance in the French shellfish farming context, since as mentioned before there is a strong correlation between the size of the company and its profitability level. Consequently, the smaller companies are supposed to have a lower economic capacity to support important external impacts. This hypothesis is tested by the size indicators water volume and total revenue.

Concerning the labor subcategory, it is composed of permanent labor and spouse status. The full-time workforce within a company is considered a major contribution to fixed costs, thus producing a negative factor against commercial bans. Most of the shellfish farming companies are of small size, and require the assistance of the spouse. To incorporate this aspect of the industry, the study included the spouse working status as an indicator. Status options include single, unemployed, works conjointly with the company (without salary), salaried company employee, and salaried employee elsewhere.

Finally, the finance subcategory is related to the financial management of the company as well as revenue from external sources (such as spousal income, other businesses, etc.); these are considered critical attributes that mitigate the effects of commercial bans. Simply put, companies that can continue to receive income from other activities during a commercial ban will be less impacted. The ability to maneuver financial assets and debt during a period of stress assists in the recuperation of losses.

It should be made aware that no weighting system was employed to render an indicator more influential than another; the analysis and data collection process did not produce enough information to employ with confidence a weight system. Several illustrative indicators were targeted in order to identify vulnerability correlations. These indicators were initially part of the original indicator pool described in the beginning of the methodology process. They were deselected as part of the vulnerability formation due to redundancy or lack of immediate relevance to stress (microbiological contamination). At the final selection process, only indicators from the technology subcategory have been relevant in our case study. The other indicators can be explained by many other economic reasons and motivations.

\section{Analysis of Results}

Following the methodology described in previous sections, the results of the vulnerability assessment related to microbiologic pollution are plotted in figures 2 and 3 . There is a quasilinear distribution of vulnerability indexes from companies less affected by commercial bans and to those who are highly affected. Based on this distribution, four groups of companies have been built considering changes in the distribution slope. For each group, the average vulnerability score has been calculated. It should be again noted that the scores are comparative and are not in absolute terms. In terms of microbiologic contamination and risk management, the vulnerability level of each company is relative to other companies operating in the Thau Lagoon. 
Figure 2: Vulnerability Index by Company

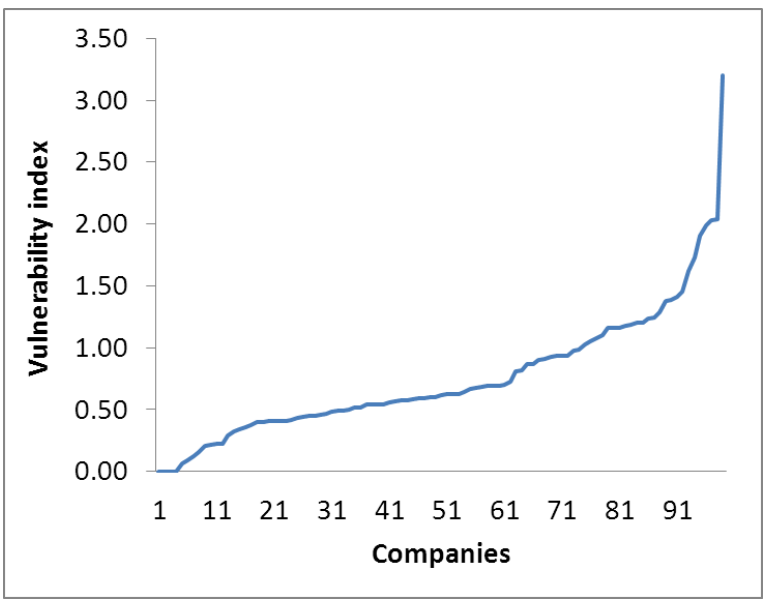

Figure 3: Vulnerability Average by Vulnerability Group

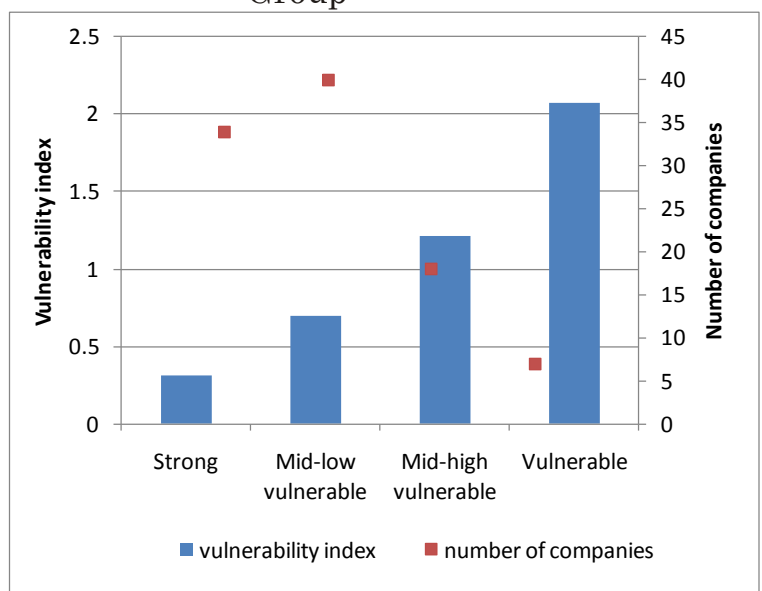

Figure 3 shows that 7 companies, group Vulnerable, have a vulnerability score higher than 1.5. They are highly vulnerable to the effects of microbiologic contamination compared to the sector at the local scale. Of the 99 companies, 34 have a vulnerability score lower than 0.5 and are considered -strong" (group Strong) they are mildly affected by commercial bans. Forty companies are considered as Mid-low vulnerable and have a vulnerability score between 0.5 and 1 . The 18 Mid-high vulnerable companies assessed have a vulnerability score between 1 and 1.5. After calculating the vulnerability score for each individual company, it is possible to explore the primary characteristics that render a company more or less impacted by microbiological pollution. First, we compare the vulnerability level with respect to the specialization of companies. The results show (cf. Table 5) that the most vulnerable companies are those which have a disproportionately low amount of - \$ppatching Revenue." This is evidenced by companies who fall in group Strong, who have an average dispatching percentage revenue of $15 \%$, which is 3 times higher than that of group Vulnerable. During a commercial ban due to microbiological pollution, these companies can still maintain a certain level of revenue via dispatching activities.

When reviewing company revenue with respect to species farmed, the results show that a high dependence on - Oyster Production Revenue" correlates to high vulnerability (cf. Table 5). The companies in group Strong have a significantly higher Mussel Production Revenue" percentage than those of the other groups. This observation is principally explained by the seasonal production cycles of the two species. The risk of having a commercial ban declared during oyster season is much higher than that of mussel season. A change in this pattern of commercial ban occurrences would alter company vulnerability levels.

Table 5: $\quad$ Revenue Sources (indicated by \% revenue)

\begin{tabular}{lcccc}
\hline Group & $\begin{array}{c}\text { Dispatching } \\
\text { Revenue }\end{array}$ & $\begin{array}{c}\text { Oyster } \\
\text { Production } \\
\text { Revenue }\end{array}$ & $\begin{array}{c}\text { Mussel } \\
\text { Production } \\
\text { Revenue }\end{array}$ & $\begin{array}{c}\text { Revenue from } \\
\text { outside the } \\
\text { Lagoon }\end{array}$ \\
\hline Strong & $15 \%$ & $72 \%$ & $27 \%$ & $10 \%$ \\
Mid-low vulnerable & $13 \%$ & $81 \%$ & $18 \%$ & $7 \%$ \\
Mid-high vulnerable & $7 \%$ & $82 \%$ & $17 \%$ & $4 \%$ \\
Vulnerable & $5 \%$ & $85 \%$ & $14 \%$ & $2 \%$ \\
\hline
\end{tabular}

Finally, the results from Revenue from outside the Lagoon" (cf. Table 5) show that the most vulnerable companies are those who concentrate their commercial activities within the Thau 
Lagoon. Those who are less vulnerable have a certain level of commercial activity from outside of the Lagoon which allows them to be less susceptible to bans.

As previously mentioned, companies can operate where dispatching activities are either considered a primary or complementary source of revenue. This depends on the function of production and the level of income received from dispatching aspects of a company's business. In order to discover what kind of role commercial specialization plays in the context of our vulnerability study, the distribution of sample population was measured by crossreferencing these two typologies: (1) vulnerability and (2) commercial specialization (cf. Table 6).

Table 6: Vulnerability scores by commercial typology and its distribution by vulnerability group (shaded portion)

\begin{tabular}{lrrrr}
\cline { 2 - 5 } & $\begin{array}{c}\text { Simple } \\
\text { Producers }\end{array}$ & Producers & $\begin{array}{c}\text { Producers/ } \\
\text { Dispatchers }\end{array}$ & Dispatchers \\
\hline \% of trading revenue & $0 \%$ & $11-20 \%$ & $20-60 \%$ & $>60 \%$ \\
Number of companies & 30 & 54 & 9 & 6 \\
Average Vulnerability score & 0.83 & 0.77 & 0.58 & 0.57 \\
\hline Strong & $27 \%$ & $33 \%$ & $67 \%$ & $33 \%$ \\
Mid-low vulnerable & $50 \%$ & $37 \%$ & $11 \%$ & $67 \%$ \\
Mid-high vulnerable & $13 \%$ & $22 \%$ & $22 \%$ & $0 \%$ \\
Vulnerable & $10 \%$ & $7 \%$ & $0 \%$ & $0 \%$ \\
Total & $100 \%$ & $100 \%$ & $100 \%$ & $100 \%$ \\
\hline
\end{tabular}

If we focus on the last two company types of Table 6, Producers/ Dispatchers" and Eispatchers" we observe that they are principally composed of companies that fall under groups Strong and Mid-low vulnerable. It is important to note that these two company types are not represented in group Vulnerable. Simple Producers" and Producers" are the only two company types that are in group Vulnerable. If we focus on the average vulnerability score of each company type, we observe that the vulnerability score decreases as revenue of companies is obtained mainly by dispatching activities. This effect renders companies that are more specialized in production more dependent on the water quality of the lagoon.

Evaluating sensitivity by vulnerability groups enables us to measure the importance of company activity cycles with respect to risk exposure. As stated earlier, the Thau lagoon is subject to frequent commercial bans and days closed during the autumn season. Table 7 displays the average seasonal revenue by vulnerability group.

Table 7: $\quad$ Average Seasonal Revenue by vulnerability group

\begin{tabular}{lcccc}
\hline Vulnerability Group & Winter & Spring & Summer & Autumn \\
\hline Strong & $51.5 \%$ & $12.0 \%$ & $24.2 \%$ & $11.7 \%$ \\
Mid-low vulnerable & $39.6 \%$ & $18.9 \%$ & $21.0 \%$ & $20.4 \%$ \\
Mid-high vulnerable & $34.9 \%$ & $22.7 \%$ & $21.0 \%$ & $21.3 \%$ \\
Vulnerable & $26.4 \%$ & $25.0 \%$ & $13.6 \%$ & $35.0 \%$ \\
\hline
\end{tabular}

The most vulnerable companies are those who have significant production and commercial activities during the autumn, as shown by group Vulnerable (35\%). The companies who perform well against microbiologic pollution in the lagoon have significant economic activity during the winter. There is a very low probability that a commercial ban will be declared 
during winter; this is the reason why the potential impact of commercial bans is reduced for the stronger performing companies. Concerning coping mechanisms, external purifying tanks for storing capacity purposes is a key factor for mitigating the economically harmful effects of commercial bans. When comparing the technology scores (cf. Table 8) of the four vulnerability groups, we observe that the distribution of average scores decrease from the strongest performing group to the weakest. There is an approximately $10 \%$ gap in scores between each group. Group Strong has a technology score two and half times greater than group Vulnerable. The scores confirm that companies that invest in storage technology are better suited to combat against commercial bans.

Table 8: $\quad$ Average Technology Score by Group

\begin{tabular}{lc}
\hline Vulnerability Group & Average Score \\
\hline Strong & $65 \%$ \\
Mid-low vulnerable & $55 \%$ \\
Mid-high vulnerable & $34 \%$ \\
Vulnerable & $28 \%$ \\
\hline
\end{tabular}

As for the other coping capacity indicators, (cash management, company size, available credit) the analysis shows that they have little or no correlation to the vulnerability score. These other indicators can be linked to many other factors. The weaknesses of these links can be due to three reasons. Firstly, the risk of commercial ban has been low during the period analyzed. As a result, the indicators selected may not capture fully the effects of these events. Secondly, some indicators are correlated, which then requires a selective process in order to avoid the assessment of artificial interdependencies. Thirdly, some indicators can be preselected erroneously. For this study, only indicators of technology presented robust correlations with vulnerability.

The assessment of vulnerability by company type suggests that diversification and storage strategies can reduce the effects of commercial bans for shellfish farming companies. Revenues of simple producers are completely dependent on the water quality of the Thau Lagoon. Some of them can reduce the economic risks associated with these events by investing in external purifying tanks which can be used for storage processes. Inversely, companies which market products sourced from external production areas are less dependent on the local water quality. This is the reason why these types of companies do not exist in group vulnerable group; they are in either groups Mid-low vulnerable and Strong.

\section{Conclusions and Discussion}

The analysis of the differentiated effects of microbiologic pollution events allows for a better understanding on how companies respond to these risks and the degree in which they are vulnerable. The identification of the more affected agents confronted by this issue (group Vulnerable and group Mid-high vulnerable) can supply additional information for the decision making processes related to water quality at the regional scale. The adoption of specific policies targeting the more affected agents can be potentially more efficient and achievable at lower costs.

The main results obtained can be summarized by the following statements. First, in general, the scores of indicators estimated are weak. This is explained by the low risk and impact scores which have been observed over the last five years. However, the objective of this approach is to explore event-oriented changes in the sector. Through this model, different scenarios can be created and analyzed. For example, a shift in the commercial ban 
occurrence toward more sensitive periods (e.g. The Christmas period represents $50 \%$ of commercial sales for oyster farmers) would strongly change the vulnerability ratios between companies.

Second, the sensitivity and impact results show clearly the areas where companies are most vulnerable. What is suggested is a flexible product marketing strategy that involves product source, product type and seasonal distribution. Oyster production and autumn commercial bans are the most affected revenue source and season, respectfully. When comparing companies that are less vulnerable, a sensible level (related to the dynamics of the Thau lagoon) of sales involving multiple products and seasons is observed. An emulation of this type of strategy should be encouraged.

Third, the single largest driving indicator subcategory is technology, due to its influence on coping capacity. Once a commercial ban is declared, companies can only sell the products that have been already been removed from or have origins outside the Thau Lagoon. Thus, the ability of a company to purify and store shellfish products at any given moment is extremely important. It is apparent that storage capacity is indeed more important than revenue during commercial bans; this is an important statement for the sector to acknowledge. It is of no surprise that the least vulnerable companies are those that combine a multi-faceted sales strategy with a robust storage infrastructure.

And finally, although the results achieved are desirable, several deficiencies relating to information discrepancies were evident. All limits mentioned are associated to the premodeling phase which concerns data gathering. As mentioned earlier, a weight system was not employed; all indicators have the same level of influence. A more precise survey would have shed light on the importance of one indicator over another.

The results obtained represent an observation of comparative vulnerability of shellfish companies at a given moment. However, this approach hopes to evaluate how this comparative state could evolve over time, in function with ecological, political and sociological dynamics. The evolution of vulnerability can be related to any one of its three components. First, the exposure to a commercial ban can vary due to a number of parameters, notably climatic and physical location. But local policy and administrative management concerning water quality can have just as much an effect on pollution. Secondly, the economic activities of a company evolve over time which equally modifies their sensitivity to microbiological pollution. Thirdly, the investment processes are just as dynamic and could alter the effects of commercial bans. This has been shown with the utilization of technology as a coping capacity mechanism.

A comprehensive understanding is needed of the Thau lagoon shellfish industry. The interworkings of its economy and how it relates to the region will help measure climatic impacts and establish effective policy solutions. The comparative vulnerability assessment conducted here has helped shed light on an overlooked sector and could be a tool to help the local administration and companies alike mitigate microbiological contamination. Of even more significance, the methodology utilized could be replicated and applied elsewhere.

\section{Acknowledgment}

This work has been developed under the SPICOSA project framework (Science and Policy Integration for Coastal Systems Assessment). This project has been funded by the EU'S Sixth Framework Programme. The authors want to especially thank the SPICOSA team and the local stakeholders for their collaboration. 


\section{References}

- Calvet L., (1910). -L'ostréiculture à « Cette » et dans la région de l'étang de Thau. -Trav. Inst. Zool. Univ. Montpellier et Stat. zoo!. Sète, S. 2, Mém. n 20 : 1-104.

- Chapelle A., Lazure P., Souchu P. (2001). Modélisation numérique des crises anoxiques (malaïgues) dans la lagune de Thau (France). Oceanologica Acta, Volume 24, Supplement 1 , February (2001), Pages 87-97

- De Sherbinin A., Schiller A., Pulsipher A., (2007). The vulnerability of global cities to climate hazards. Environment and Urbanization 2007 19: 39

- Fiandrino, A., Martin,Y., Got, P., Bonnefont, J.L., Troussellier, M., (2003). Bacterial contamination of Mediterranean coastal seawater as affected by riverine inputs: simulation approach applied to a shellfish breeding area (Thau Lagoon, France). Water Research, 37, 1711-1722.

- Fleury, P.G., Goyard, E., Mazurie, J., Claude, S., Bouget, J.F., Langlade, A., Le Coguic, Y., (2001). The assessing of Pacific oyster (Crassostrea gigas) rearing performances by the Ifremer/Rémora network : method and first results (1993-98) in Brittany (France). Hydrobiologia 465, 195-208.

- Fauvel Y. (1967). La pollution bactérienne des eaux et des coquillages de l'étang de Thau. Rev. Tray. ISTPM

- Gangnery A., Chabirand J.M., Lagarde F., Le Gall P., Oheix J., Bacher C., Buestel D. (2003). Growth model of the Pacific oyster, Crassostrea gigas, cultured in Thau Lagoon (Mediterranee, France). Aquaculture, 215(1-4), 267-290

- Gervasoni E., Perignon A., Sourisseau E., Rey Valette H., Lagarde F., Pérez Agúndez J.A, Yimam E., Feldman N. (2011). La conchyliculture en Méditerranée. Monographie. http://archimer.ifremer.fr/doc/00124/23509/

- Girard S., Pérez Agúndez J.A., Miossec L., Czerwinski N. (2005). Recencement de la conchyliculture 2001. Agreste cahiers, numéro 1, février 2005. Paris : MAAPAR, Direction des affaires financiers, SCEES pages ?

- Girard S., Pérez Agúndez J.A., Van Iseghem S., (2009) " Typologie d'entreprises conchylicoles : Analyse à partir des données du recensement de la conchyliculture française 2002 ». Publications électroniques Amure, Série Rapport, R-14-2009. (http://www.umr-amure.fr/electro rapports amure/R 14 2009.pdf).

- Hahn, M. B., A. M. Riederer, and S.O. Foster (2009). "The Livelihood Vulnerability Index: A pragmatic approach to assessing risks from climate variability and change-A case study in Mozambique." Global Environmental Change 19(1): 74-88.

- Hambry, J. (2002). Financial analysis and risk assessment of selected aquaculture and fishery activities in the Mekong Basin. MRC Technical Paper No. 5, Mekong River Commission, Phnom Penh. 67 (April 2002) pp. ISSN: 1683-1489

- Harzallah A. and Chapelle A., (2002). Contribution of climate variability to occurrences of anoxic crises malaïgues' in the Thau Lagoon (southern France). Oceanologica Acta 25 (2002) 79-86.

- Ippolito A., Sala S., Faber J H. and Vighi M. (2010), Ecological vulnerability analysis: A river basin case study," Science of The Total Environment 408, no. 18 (Août 15, 2010): 3880-3890.

- Luers A.L., Lobell D.B., Sklar L.S., Addams C.L., Matson P. A. (2003). A method for quantifying vulnerability, applied to the agricultural system of the Yaqui Valley, Mexico," Global Environmental Change 13, no. 4 (Décembre 2003): 255-267.

Mathé S., Rey-Valette H., Pagès S. (2006). Occurrence et évaluation économique d'une fermeture de l'étang de Thau pour cause bactériologique. Rapp. DITTY, Development of an Information Technology Tool for the Management of European Southern Lagoons. Janvier 2006, $69 \mathrm{p}$. 
- Mohan D. and Sinha S. (2010) Vulnerability Assessment of People, Livelihoods and Ecosystems in the Ganga Basin. Living Ganga Programme - Climate Adaptation Project Team. WWF-India.

- Mongruel R., Pérez Agúndez J.A. (2012) Aational policy objectives and local management results: the economic, social and environmental performances of the shellfish farming institutions in the Mont-Saint-Michel Bay (France)" Society and Natural Resources: An International Journal, 25(4): 352-367.

- Rémi Mongruel, Alice Vanhoutte-Brunier, Annie Fiandrino, François Valette, Johanna Ballé-Béganton, José A. Pérez Agúndez, Nicola Gallai, Valérie Derolez, Sébastien Roussel, Michel Lample, Thierry Laugier (2013). Why, how, and how far should microbiological contamination in a coastal zone be mitigated? An application of the systems approach to the Thau lagoon (France), Journal of Environmental Management, Volume 118, 30 March, Pages 55-71

- Munier, N. (2011). Methodology to select a set of urban sustainability indicators to measure the state of the city, and performance assessment. Ecol. Indicat. Volume 11, Issue 5, September 2011, Pages 1020-1026

- Pelling, M. (2003). The Vulnerability of Cities. Natural Disasters and Social Resilience.

Earthscan Publications, London, $219 \mathrm{p}$.

- Pérez Agúndez, J.A., Mongruel, R. (2010). Technological adaptation to harmful algal bloom events: a socioeconomic analysis. ICES Annual Science Conference. 20-24 September 2010, Nantes, France.

- Pérez Agúndez et al, 2013 (Aquaculture Economics and Management, in press)

- Pérez Agúndez J. A, Mongruel R., Girard S., Cochet J.M., (2010) « Viabilité économique des procédés de sauvegarde et détoxification accélérée de coquillages cultivés face aux efflorescences de microalgues toxiques ", Publications électroniques Amure, Série Rapport, R-16-2010, httpp://www.umr-amure.fr/electro_rapports_amure/R_16_2010.pdf, 66 pages.

- Roncin N., Kervarec F. et Boncoeur J. (2001) Evaluation économique des dommages liés à la contamination microbiologique des eaux côtières Le cas de la conchyliculture. Rapport d'étude Institut Universitaire Européen de la Mer. 78 p. http://archimer.ifremer.fr/doc/00000/1739/

- Schröder D., Polsky C., Patt A.G. (2005). Assessing Vulnerabilities to the Effects of Global Change: An Eight-Step Approach. Mitigation and Adaptation Strategies for Global Change (2005) 10: 573-596.

- Simon S. and Proops J.L.R. (2000). Greening the accounts. Current issues in ecological economics. Edward Elgar Publishing Ltd., 261 p.

- Stelzenmüller V., Ellis J. R. and Rogers S. I. (2010). Fowards a spatially explicit risk assessment for marine management: Assessing the vulnerability of fish to aggregate extraction," Biological Conservation 143, no. 1 (Janvier 2010): 230-238.

- Taubenböck H., Roth A., Dech S. (2007). Vulnerability assessment using remote sensing: The earthquake prone megacity Istanbul, Turkey. In: Proceedings of ISRSE 2007, 32nd International Symposium on Remote Sensing on Environment, 2007-06-25 - 2007-06-29, San Jose, Costa Rica.

- Turner B.L.,, Kasperson R.E., Matson P., McCarthy J.J., Corell R.W., Christensen L., Eckley N., Kasperson J.X., Luers A., Martello M.L., Mathiesen S., Polsky C., Pulsipher A., Schiller A., Tyler N. (2003). A framework for vulnerability analysis in sustainability science, Proceedings of the National Academy of Sciences USA 100, pp. 8074-8079. Full Text via CrossRef | View Record in Scopus | Cited By in Scopus (260)

- Villagran de Leon, J.C. (2006). Vulnerability: A conceptual and methodological review." Studies Of the University: Research, Counsel, Education - Publication Series of UNUEHS. No. 2/2006. Bonn, Germany. 68 p.

- White P., Pelling, M., Sen, K., Seddon D., Russell, S., and Few, R. (2005). Disaster Risk Reduction. A Development Concern. DFID. 